
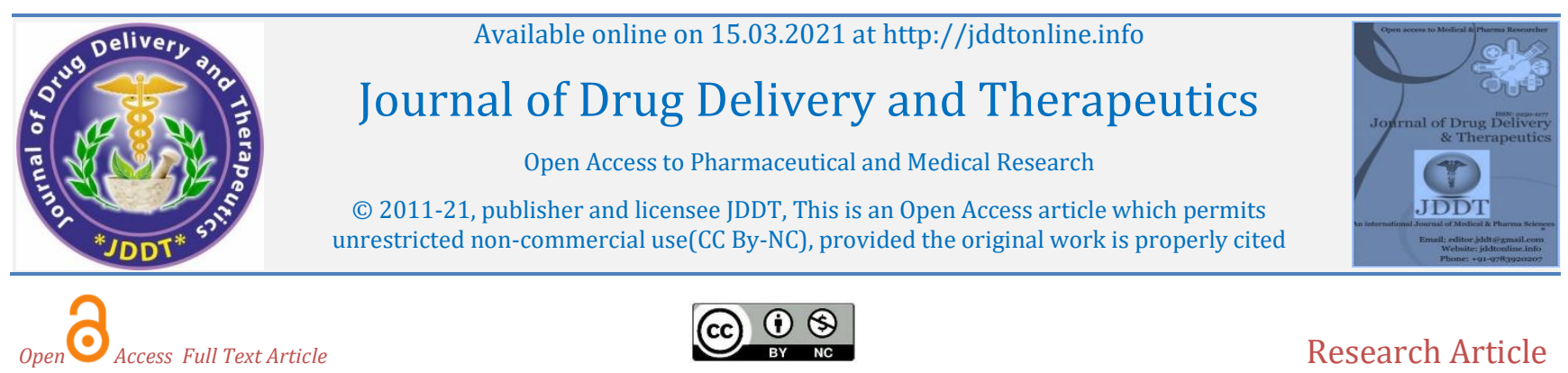

Research Article

\title{
Formulation of Metformin Sustained Release Tablet Using Natural Polymer
}

\author{
Mehak Siddiqui, L. K. Omray, Pushpendra Soni \\ Radharaman Institute of Pharmaceutical Science, Bhadbhada Road Ratibad, Bhopal MP 462046 India
}

\section{Article Info:

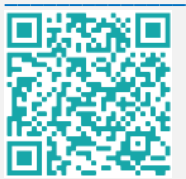 \\ Article History: \\ Received 04 Jan 2021; \\ Review Completed 17 Feb 2021 \\ Accepted 23 Feb 2021; \\ Available online 15 March 2021}

Cite this article as:

Siddiqui M, Omray LK, Soni P, Formulation of Metformin Sustained Release Tablet Using Natural Polymer,

Journal of Drug Delivery and Therapeutics. 2021;

11(2):31-37

DOI: http://dx.doi.org/10.22270/jddt.v11i2.4579

\begin{abstract}
The overall objective of the present work was to develop an oral sustained-release (SR) Metformin tablet that is prepared by the direct compression method by using hydrophilic hydroxyl propyl methyl cellulose (HPMC) and Guar gum polymer alone as well as in combination at different concentrations. Metformin is a biguanide that has a relatively short plasma half-life. It has low absolute bioavailability. All the properties were evaluated for thickness, weight variation, hardness and drug content uniformity and in vitro drug release. The mean dissolution time is used to characterize the drug release rate from a dosage form that indicates the drug release-retarding efficiency of the polymer. The hydrophilic matrix of HPMC alone could not control the Metformin release effectively for $12 \mathrm{~h}$ but when combined with Guar gum, it could slow down the release of drug and, thus, can be successfully employed for formulating Sustain Release matrix tablets.
\end{abstract}

Keywords: Guar gum, hydroxylpropylmethylcellulose, matrix tablets, release kinetics,

\section{*Address for Correspondence:}

Mehak Siddiqui, Radharaman Institute of Pharmaceutical Science, Bhadbhada Road Ratibad, Bhopal MP 462046 India

\section{INTRODUCTION}

Sustained release dosage forms are designed to achieve a prolonged therapeutic effect by continuously releasing medication over an extended period of time after administration of single dose. The main aim of preparing sustained release formulations was intended to modify and improve the drug performance by increasing the duration of drug action, decreasing the frequency of dosing, decreasing the required dose employed and providing uniform drug delivery 1 .

During the last 2-3 decades there has been remarkable increase in interest in sustained release drug delivery system. This has been due to various factor viz. the prohibitive cost of developing new drug entities, expiration of existing international patents, discovery of new polymeric materials suitable for prolonging the drug release, and the improvement in therapeutic efficiency and safety achieved by these delivery systems 2,3 .

Sustained release dosage forms are prepared by coating the tablets so that the rate of solubility is controlled or individually encapsulating micro particles of varying sizes so that the rate of dissolution can be controlled. Keating listed the following advantages of adsorbing basic nitrogen containing drug onto strong acid cation exchange resins and using them in dosage forms: Prolonged release of drug from the complex for 8-12 hours in the GI tract. SRDDS reduced the toxicity by slowing drug absorption, improved palatability, and availability of formulation in liquid and solid SRDDS, increased stability by protecting the drug from hydrolysis or other degradative changes in the gastrointestinal tract. Very early on, due consideration has to be given to their pharmacokinetics in order to obtain that specific release profile which guarantees optimum therapeutic efficiency 4-5. Enclosing drugs in diffusioncontrolled membranes is an important basic principle of controlled time release. Combining neutral, permeable polymers with anionic soluble types permits realization of various release mechanisms, while paying due regard to the physicochemical properties of the drug. Sustain drug action at a predetermined rate by maintaining a relatively constant, effective drug level in the body with concomitant minimization of undesirable side effects associated with a saw tooth kinetic pattern. In short, Sustained release formulations (e.g., Aspirin SR, Dextrim SR) describe the slow release of a drug substance from a dosage form to maintain therapeutic response for extended period (e.g., 8-24 hours) of time. In oral form it is in hours, and in parenteral it is in days and months 6-8. Controlled release (e.g., Adalat CR tablet for nifedipine, Dynacirc CR tablet for isradipine) dosage form describes the rate or speed at which the drug is released is controlled ${ }^{9-12}$.

The oral route of administration for sustained release systems has received greater attention because of more flexibility in dosage form design. The design of oral sustained release delivery systems is subjected to several interrelated 
variables of considerable importance such as the type of delivery system, the disease being treated, the patient, the length of therapy and the properties of the drug. Ideally a sustained release oral dosage form is designed to release rapidly some predetermined fraction of the total dose into GI tract. 13 .

\section{MATERIALS AND METHODS}

\section{Drug Profile}

\section{Selected Drug: Metformin}

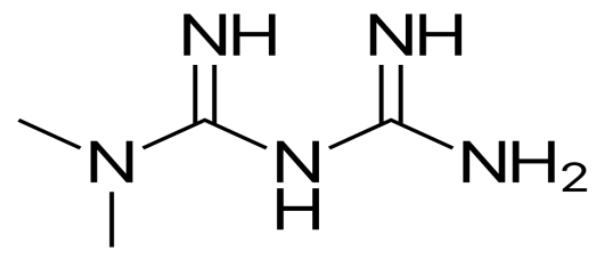

Structure of Metformin
Molecular Formula: $\mathrm{C}_{4} \mathrm{H}_{11} \mathrm{~N}_{5}$

Molecular Weight: Average: 129.1636

Chemical Name: 1-carbamimidamido-N,N-

dimethylmethanimidamide

Synonym: Dimethylbiguanid

Melting Point: $223-226^{\circ} \mathrm{C}$

Physical Description: Solid

Solubility: $2 \mathrm{~g}$ of Metformin hydrochloride is soluble in $10 \mathrm{~mL}$ of water

\section{Materials}

Metformin, Manila copal, Guar gum, Pectin, Microcrystalline cellulose, PVP K30, Talc and Magnesium stearate, all the chemical were purchased from Standard chemicals Mumbai

Formulation for Design of Sustained Release Tablets of Metformin

Table 1: Design of Sustained Release Tablets of Metformin

\begin{tabular}{|c|c|c|c|c|c|c|c|c|c|c|c|c|}
\hline $\begin{array}{c}\text { Formulation Code } \\
\text { / } \\
\text { compositions }\end{array}$ & $\begin{array}{c}\text { F1 } \\
(\mathbf{m g})\end{array}$ & $\begin{array}{c}\text { F2 } \\
\text { (mg) }\end{array}$ & $\begin{array}{c}\text { F3 } \\
\text { (mg) }\end{array}$ & $\begin{array}{c}\text { F4 } \\
(\mathrm{mg})\end{array}$ & $\begin{array}{c}\text { F5 } \\
\text { (mg) }\end{array}$ & $\begin{array}{c}\text { F6 } \\
(\mathrm{mg})\end{array}$ & $\begin{array}{c}\text { F7 } \\
\text { (mg) }\end{array}$ & $\begin{array}{c}\text { F8 } \\
(\mathrm{mg})\end{array}$ & $\begin{array}{c}\text { F9 } \\
\text { (mg) }\end{array}$ & $\begin{array}{l}\text { F10 } \\
\text { (mg) }\end{array}$ & $\begin{array}{c}\text { F11 } \\
\text { (mg) }\end{array}$ & $\begin{array}{l}\text { F12 } \\
\text { (mg) }\end{array}$ \\
\hline Metformin & 20 & 20 & 20 & 20 & 20 & 20 & 20 & 20 & 20 & 20 & 20 & 20 \\
\hline Manila copal & 10 & 20 & 40 & 60 & - & - & - & - & - & - & - & - \\
\hline Guargum & - & - & - & - & 10 & 20 & 30 & 40 & - & - & - & - \\
\hline Pectin & - & - & - & - & - & - & - & - & 10 & 20 & 30 & 40 \\
\hline $\begin{array}{c}\text { Microcrystalline } \\
\text { cellulose }\end{array}$ & 63.8 & 53.8 & 33.8 & 13.8 & 63.8 & 53.8 & 33.8 & 13.8 & 63.8 & 53.8 & 33.8 & 13.8 \\
\hline PVP K30 & 5 & 5 & 5 & 5 & 5 & 5 & 5 & 5 & 5 & 5 & 5 & 5 \\
\hline Talc & 0.6 & 0.6 & 0.6 & 0.6 & 0.6 & 0.6 & 0.6 & 0.6 & 0.6 & 0.6 & 0.6 & 0.6 \\
\hline $\begin{array}{l}\text { Magnesium } \\
\text { stearate }\end{array}$ & 0.6 & 0.6 & 0.6 & 0.6 & 0.6 & 0.6 & 0.6 & 0.6 & 0.6 & 0.6 & 0.6 & 0.6 \\
\hline Total & 100 & 100 & 100 & 100 & 100 & 100 & 100 & 100 & 100 & 100 & 100 & 100 \\
\hline
\end{tabular}

\section{Formulation of Metformin Tablets:}

The tablets were prepared by following the General Methodology as given below:

- The procedure followed was direct compression

- The drug and all the excipients except magnesium stearate and talc were weighed

- Appropriately and were passed through sieve no.30. Magnesium stearate and talc were passed through mesh no.60.

- All the ingredients were mixed thoroughly in a polythene bag and compressed to a tablet.

\section{Evaluation of Blend Characteristics:}

Pre compression characteristics of Metformin tablets

\section{Drug and Excipient compatibility studies}

FTIR spectroscopy was carried for pure drug and polymers to know any chemical interactions between polymers and drug. The samples of pure drug, polymers and physical mixture of drug and polymers were dispersed in $200 \mathrm{mg}$ of $\mathrm{KBr}$ powder and compressed into pellets at a pressure of $6000 \mathrm{~kg} / \mathrm{cm}^{2}$ and analyzed. Spectral measurements were obtained by powder diffuse reflectance on a FT-infrared spectrophotometer (Shimadzu, FT-IR, Japan) in the range $4000-400 \mathrm{~cm}^{-1}$.

\section{Angle of repose}

The flow property was determined by measuring the Angle of Repose. In order to determine the flow property, the Angle of Repose was determined. It is the maximum angle that can be obtained between the free standing surface of a powder heap and the horizontal plane.

$\theta=\tan -1(\mathrm{~h} / \mathrm{r})$

Where,

$\mathrm{h}=$ height

$\mathrm{r}=$ radius

$\theta=$ angle of repose 


\section{Compressibility Index:}

The flow property was also determined by measuring the compressibility index (I) (flow ability). A simple indication of the case with which a material can be induced to flow is given by application of a compressibility index (I) given by equation.

$$
\mathrm{I}=\left[\mathbf{1}-\left(\mathrm{V} / \mathrm{V}_{\mathbf{0}}\right)\right] \times \mathbf{1 0 0}
$$

Where, $\mathrm{V}=$ the volume occupied by a sample of the power after being subjected to a standardized tapping procedure (after 500 vibrations) $\mathrm{V}_{0}=$ in the volume before tapping

\section{Evaluation of post compression characteristics}

The following evaluation of tablets was performed.

Weight variation, Hardness, Friability, Content uniformity

\section{Weight Variation}

The USP weight variation test was run by weighing 20 tablets individually, calculating the average weight, and comparing the individual tablet weights to the average. The tablets met the USP test that was no more than 2 tablets were outside the percentage limit and no tablets differed by more than 2 times the percentage limit.

\section{Hardness}

Hardness of the tablets was determined by breaking it between the second and third fingers with thumb being as a fulcrum. There was a sharp snap the tablet was deemedto have acceptable strength. Hardness of the tablets are also determined by Stokes Monsanto Hardness Tester and the hardness should be found within the range of 3.5-5.5 $\mathrm{kg} / \mathrm{cm}^{2}$.

\section{Friability}

The friability of tablets was determined by Roche friabilator. 20 tablets were taken and weighed. After weighing the tablets were placed in the Roche friabilator and subjected to the combined effects of abrasion and shock by utilizing a plastic chamber that revolves at 25RPM / 100 revolutions by dropping the from a distance of six inches with each revolution after operation the tablets were deducted and reweighed.

Friability is determined by $\mathrm{F}=100(1-\mathrm{Wo} / \mathrm{Wt})$

Where, $\mathrm{Wo}=\mathrm{wt}$. of tablets before friability test, $\mathrm{Wt}=\mathrm{wt}$. of tablets after friability test.

\section{Content Uniformity}

Five tablets were weighed and powdered, $10 \mathrm{mg}$ of equivalent of Metformin was weighed and dissolved in suitable quantity of methanol, the solution was filtered suitably diluted and the drug content was analyzed using UV spectrometer at $300 \mathrm{~nm}$.

Table 2: Weight Variation Tolerance for Uncoated Tablets

\begin{tabular}{|c|c|c|}
\hline S. No & $\begin{array}{c}\text { Average weight } \\
\text { of tablets (mg) }\end{array}$ & $\begin{array}{c}\text { Maximum percentage } \\
\text { (\%) difference } \\
\text { allowed }\end{array}$ \\
\hline 1 & 130 or less & 10 \\
\hline 2 & 130 to 324 & 7.5 \\
\hline 3 & More than 324 & 5 \\
\hline
\end{tabular}

In -Vitro Dissolution Studies of Metformin Sustained Released Tablets Apparatus II (Paddle Method)

The same equipment as in apparatus I was used, expected that a paddle replaced the basket, formed from a blade and a shaft as a stirring element. The dosage form was allowed to sink to the bottom of the flask before stirring. A constant temperature of $37 \pm 0.5 \stackrel{\circ}{\circ} \mathrm{C}$ was maintained. The motor was adjusted to turn at the specified speed of 50rpm, and the samples of the fluid were withdrawn at intervals to determine the amount of drug in solution.

\section{Dissolution of Metformin Sustained Release Tablets}

The dissolution test was carried out using USP apparatus II (Lab India disso 2000).Stirring speed was maintained at 50 rpm. $6.8 \mathrm{pH}$ phosphate buffers were used as dissolution medium $(900 \mathrm{ml})$ and were maintained at $37 \pm 0.5 \mathrm{c}$. Samples of specified volume were withdrawn at predetermined time intervals, filtered, dilute suitably and assayed spectrophotometrically. An equal volume of fresh medium was immediately replaced to maintain the dissolution volume. The sample was analyzed spectrophotometrically at $300 \mathrm{~nm}$. Using spectrophotometer to assay the amount of Metformin released at each time interval.

\section{RESULTS AND DISCUSSION}

\section{Preformulation Studies}

Table 3: Pre-formulation study results of Metformin

\begin{tabular}{|c|c|c|c|}
\hline S. No. & Test & Specification & Results \\
\hline \multirow{2}{*}{1.} & Organoleptic properties & & \\
\cline { 2 - 4 } & Colour & White to off-white & White to off-white \\
\cline { 2 - 4 } & Odour & Odourless & Odourless \\
\hline 2. & Nature & Amorphous & Amorphous \\
\hline 3. & Solubility & Nlightly soluble in water & Slightly soluble in Water \\
\hline 4. & LOD & $226^{\circ} \mathrm{C}$ & $0.25 \%$ \\
\hline 5. & Melting Point & NLT $98.0 \%$ and NMT $102.0 \%$ & 226 C \\
\hline 6. & Assay & $3-5 \mathrm{~mm}$ & $99.86 \%$ \\
\hline
\end{tabular}


Flow properties of Metformin:

Table 4: Flow properties of Metformin

\begin{tabular}{|c|c|c|}
\hline S. No. & Parameter & Results \\
\hline 1 & Bulk density (gm/cc) & $0.55 \mathrm{gm} / \mathrm{cc}$ \\
\hline 2 & Tapped Density (gm/cc) & $0.64 \mathrm{gm} / \mathrm{cc}$ \\
\hline 3 & Compressibility Index (\%) & $16.36 \%$ \\
\hline 4 & Hausner's Ratio & 1.16 \\
\hline
\end{tabular}

Drug and excipients compatibility studies

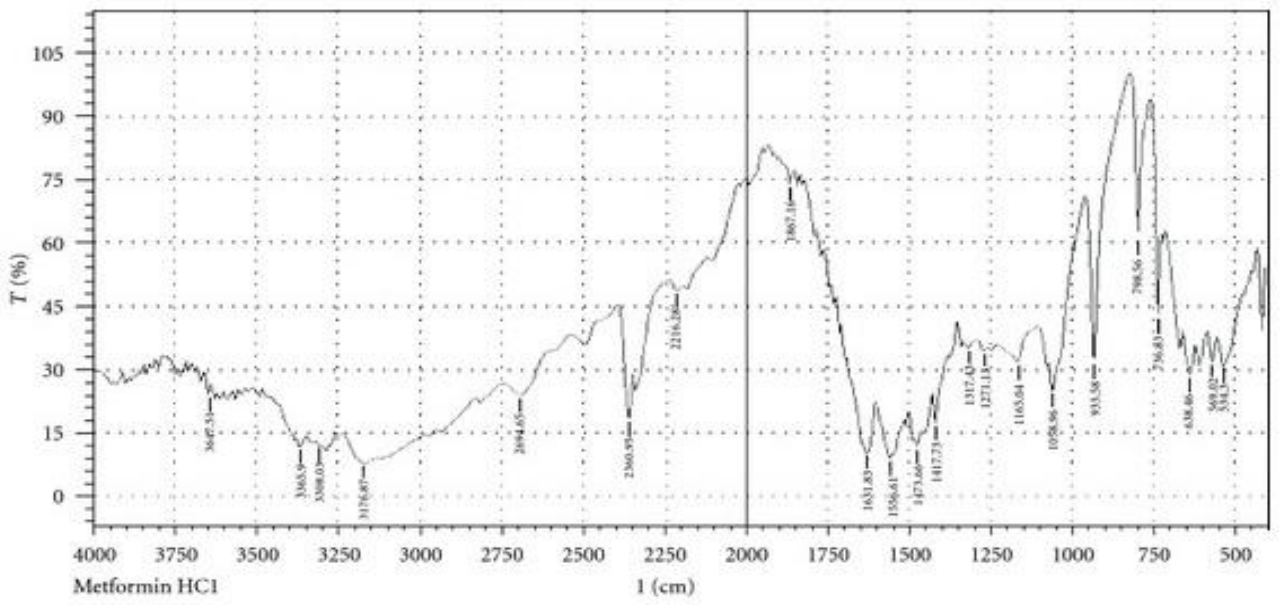

Figure 1: FTIR spectra of pure Metformin

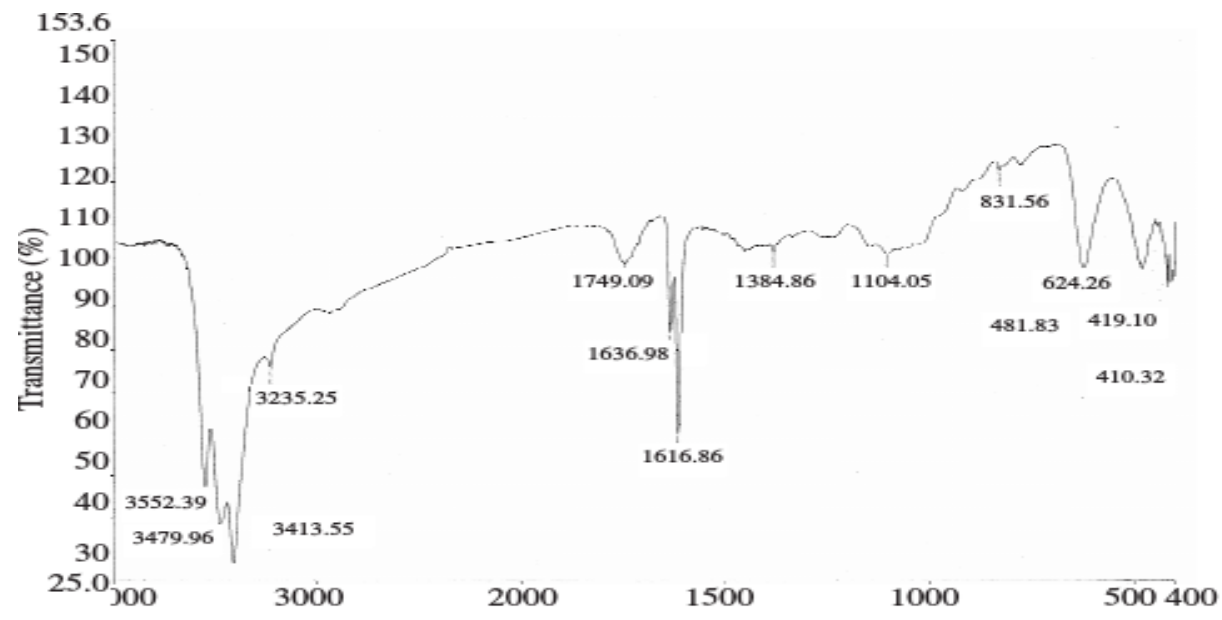

Figure 2: FTIR spectra of pectin

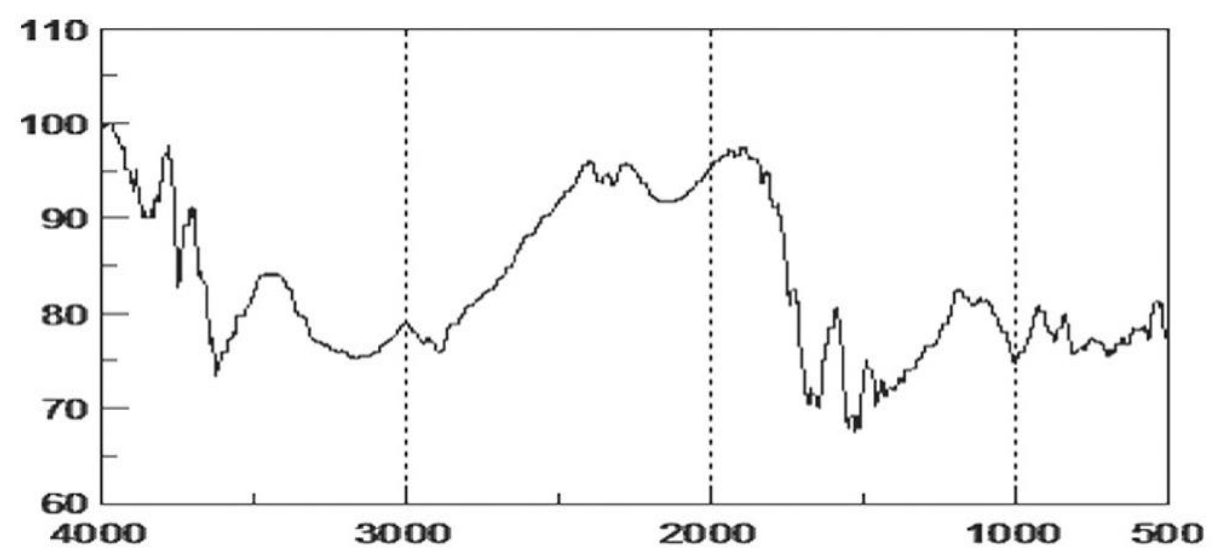

Figure 3: FTIR spectra of Guar gum 


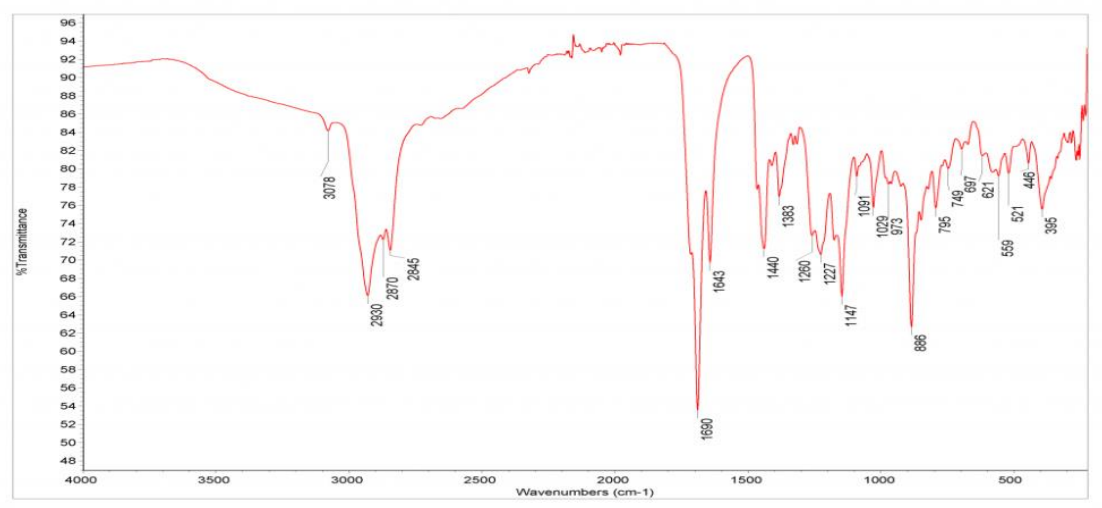

Figure 4: FTIR spectra of Manila copal

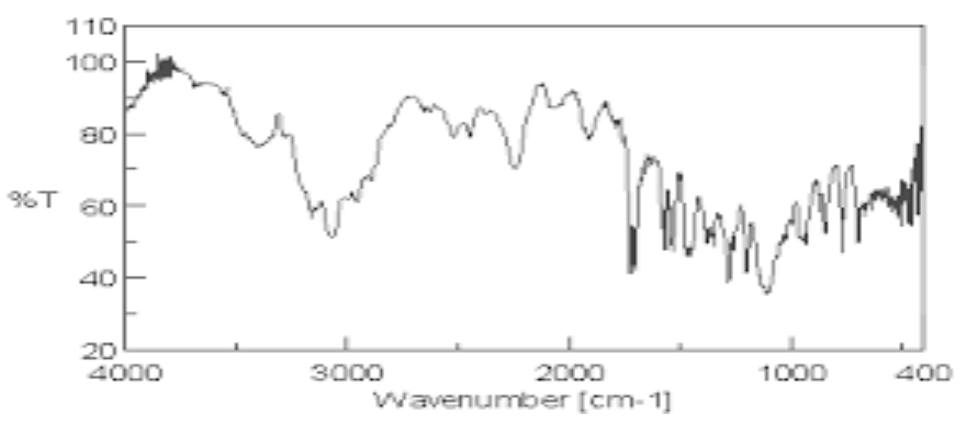

Figure 5: FTIR spectra of physical mixture of Metformin and polymers

\section{Preparation of calibration curve for Metformin}

$1 \mathrm{gm}$ of Metformin was dissolved in $100 \mathrm{ml}$ of pH 6.8 buffer by slight shaking $(1000 \mathrm{mcg} / \mathrm{ml})$. From the stock solution, suitable serial dilutions were made to get the concentrations of 1,3,5, 7 and $9 \mu \mathrm{g} / \mathrm{ml}$ in $\mathrm{pH} 6.8$ phosphate buffer solutions.

Table 5: Calibration curve of Metformin

\begin{tabular}{|c|c|c|}
\hline S. No & Concentration $(\boldsymbol{\mu g} / \mathbf{m l})$ & Absorbance $(\boldsymbol{\lambda} \mathbf{m a x}=\mathbf{3 0 0 n m})$ \\
\hline 1 & 1 & 0.035 \\
\hline 2 & 3 & 0.110 \\
\hline 3 & 5 & 0.191 \\
\hline 4 & 7 & 0.280 \\
\hline 5 & 9 & 0.367 \\
\hline
\end{tabular}

Table 6: Results of pre formulation evaluation

\begin{tabular}{|c|c|c|c|c|c|}
\hline $\begin{array}{c}\text { Formulation } \\
\text { code/Parameter }\end{array}$ & Bulk density & $\begin{array}{c}\text { Tapped } \\
\text { density }\end{array}$ & $\begin{array}{c}\text { Angle of } \\
\text { repose }\end{array}$ & $\begin{array}{c}\text { Compressibility } \\
\text { Index }\end{array}$ & $\begin{array}{c}\text { Hausner's } \\
\text { ratio }\end{array}$ \\
\hline F1 & $0.462 \pm 0.01$ & $0.591 \pm 0.06$ & $26.06 \pm 0.12$ & 21.8 & 1.25 \\
\hline F2 & $0.469 \pm 0.01$ & $0.561 \pm 0.02$ & $25.42 \pm 0.98$ & 21.39 & 1.19 \\
\hline F3 & $0.46 \pm 0.02$ & $0.55 \pm 0.01$ & $22.62 \pm 0.28$ & 16.36 & 1.19 \\
\hline F4 & $0.59 \pm 0.05$ & $0.68 \pm 0.04$ & $29.19 \pm 1.20$ & 13.04 & 1.15 \\
\hline F5 & $0.49 \pm 0.06$ & $0.57 \pm 0.07$ & $27.40 \pm 1.21$ & 14.04 & 1.16 \\
\hline F6 & $0.48 \pm 0.02$ & $0.55 \pm 0.06$ & $26.06 \pm 0.90$ & 12.72 & 1.14 \\
\hline F7 & $0.46 \pm 0.02$ & $0.53 \pm 0.06$ & $24.38 \pm 1.21$ & 13.20 & 1.15 \\
\hline F8 & $0.43 \pm 0.04$ & $0.49 \pm 0.04$ & $23.72 \pm 1.23$ & 12.74 & 1.14 \\
\hline F9 & $0.41 \pm 0.03$ & $0.47 \pm 0.01$ & $21.94 \pm 2.12$ & 11.36 & 1.12 \\
\hline F10 & $0.39 \pm 0.02$ & $0.44 \pm 0.02$ & $20.48 \pm 1.33$ & 14.06 & 1.16 \\
\hline F11 & $0.55 \pm 0.21$ & $0.64 \pm 0,02$ & $26.21 \pm 1.78$ & 13.11 & 1.15 \\
\hline F12 & $0.53 \pm 0 . F 02$ & $0.61 \pm 0.02$ & $25.74 \pm 1.23$ & & 14 \\
\hline
\end{tabular}


Table 7: In vitro evaluation percentage of drug results

\begin{tabular}{|c|c|c|c|c|c|c|c|c|c|c|c|c|}
\hline $\begin{array}{l}\text { Time } \\
\text { (hr) }\end{array}$ & $\begin{array}{c}\text { F1 } \\
\text { (\%) }\end{array}$ & $\begin{array}{c}\text { F2 } \\
\text { (\%) }\end{array}$ & $\begin{array}{c}\text { F3 } \\
\text { (\%) }\end{array}$ & $\begin{array}{c}\text { F4 } \\
(\%)\end{array}$ & $\begin{array}{c}\text { F5 } \\
\text { (\%) }\end{array}$ & $\begin{array}{c}\text { F6 } \\
\text { (\%) }\end{array}$ & $\begin{array}{c}\text { F7 } \\
\text { (\%) }\end{array}$ & $\begin{array}{c}\text { F8 } \\
(\%)\end{array}$ & $\begin{array}{c}\text { F9 } \\
\text { (\%) }\end{array}$ & $\begin{array}{l}\text { F10 } \\
(\%)\end{array}$ & $\begin{array}{l}\text { F11 } \\
\text { (\%) }\end{array}$ & F12(\%) \\
\hline 1 & $42 \pm 1.2$ & $43 \pm 2.2$ & $31 \pm 1.1$ & $32 \pm 1.8$ & $42 \pm 2.4$ & $33 \pm 2.1$ & $26 \pm 1.5$ & $22 \pm 1.8$ & $46 \pm 1.9$ & $44 \pm 1.0$ & $36 \pm 2.4$ & $32 \pm 2.6$ \\
\hline 2 & $54 \pm 1.0$ & $54 \pm 2.8$ & $43 \pm 1.2$ & $38 \pm 1.4$ & $56 \pm 3.3$ & $43 \pm 2.0$ & $38 \pm 1.7$ & $32 \pm 4.3$ & $57 \pm 2.2$ & $58 \pm 1.1$ & $43 \pm 1.7$ & $41 \pm 2.2$ \\
\hline 4 & $65 \pm 3.1$ & $61 \pm 2.2$ & $52 \pm 1.4$ & $46 \pm 1.7$ & $61 \pm 3.4$ & $57 \pm 4.8$ & $46 \pm 1.1$ & $41 \pm 2.2$ & $67 \pm 3.3$ & $66 \pm 1.3$ & $55 \pm 1.3$ & $51 \pm 2.0$ \\
\hline 6 & $72 \pm 2.9$ & $69 \pm 2.6$ & $64 \pm 1.0$ & $58 \pm 2.1$ & $68 \pm 3.3$ & $65 \pm 3.2$ & $52 \pm 1.2$ & $48 \pm 1.2$ & $76 \pm 2.1$ & $72 \pm 2.2$ & $67 \pm 2.4$ & $63 \pm 2.8$ \\
\hline 8 & $86 \pm 2.2$ & $76 \pm 2.4$ & $67 \pm 1.9$ & $66 \pm 2.2$ & $75 \pm 3.9$ & $72 \pm 2.1$ & $64 \pm 2.1$ & $56 \pm 3.1$ & $93 \pm 1.8$ & $86 \pm 2.8$ & $74 \pm 3.2$ & $69 \pm 1.8$ \\
\hline 10 & $92 \pm 1.1$ & $84 \pm 2.9$ & $82 \pm 1.1$ & $72 \pm 2.8$ & $86 \pm 3.5$ & $83 \pm 2.2$ & $76 \pm 2.9$ & $62 \pm 3.4$ & $98 \pm 1.2$ & $95 \pm 3.1$ & $85 \pm 3.8$ & $82 \pm 1.4$ \\
\hline 12 & $97 \pm 3.2$ & $93 \pm 3.0$ & $89 \pm 1.3$ & $85 \pm 2.2$ & $93 \pm 2.2$ & $89 \pm 3.5$ & $83 \pm 2.7$ & $69 \pm 2.8$ & & $98 \pm 2.1$ & $94 \pm 0.8$ & $89 \pm 3.1$ \\
\hline 14 & & $98 \pm 3.8$ & $93 \pm 1.8$ & $92 \pm 2.3$ & $98 \pm 0.1$ & $94 \pm 3.3$ & $88 \pm 2.2$ & $74 \pm 1.2$ & & & $98 \pm 1.8$ & $93 \pm 3.3$ \\
\hline 16 & & & $98 \pm 1.8$ & $94 \pm 2.9$ & & $98 \pm 3.2$ & $92 \pm 2.1$ & $82 \pm 1.1$ & & & & $95 \pm 2.3$ \\
\hline 18 & & & & $97 \pm 1.1$ & & & $95 \pm 0.2$ & $90 \pm 0.4$ & & & & $97 \pm 2.1$ \\
\hline 20 & & & & & & & $98 \pm 1.1$ & $93 \pm 1.9$ & & & & \\
\hline 22 & & & & & & & & $97 \pm 0.9$ & & & & \\
\hline 24 & & & & & & & & $99 \pm 1.0$ & & & & \\
\hline
\end{tabular}

Table 8: Results of post compression evolution

\begin{tabular}{|c|c|c|c|c|}
\hline $\begin{array}{c}\text { Formulation } \\
\text { code/Parameter }\end{array}$ & Hardness(units) & $\begin{array}{c}\text { Weight } \\
\text { Variation }\end{array}$ & Friability (\%) & $\begin{array}{c}\text { Content } \\
\text { uniformity }\end{array}$ \\
\hline F1 & $3.0 \pm 0.02$ & PASS & $0.18 \pm 0.02$ & $99.17 \pm 1.5$ \\
\hline F2 & $3.1 \pm 0.03$ & PASS & $0.22 \pm 0.02$ & $99.44 \pm 1.2$ \\
\hline F3 & $3.0 \pm 0.71$ & PASS & $0.43 \pm 0.04$ & $98.64 \pm 2.8$ \\
\hline F4 & $3.2 \pm 0.03$ & PASS & $0.20 \pm 0.02$ & $99.17 \pm 2.8$ \\
\hline F5 & $3.0 \pm 0.06$ & PASS & $0.22 \pm 0.06$ & $99.44 \pm 2.0$ \\
\hline F6 & $3.0 \pm 0.04$ & PASS & $0.45 \pm 0.04$ & $99.64 \pm 2.6$ \\
\hline F7 & $3.0 \pm 0.03$ & PASS & $0.24 \pm 0.02$ & $100.2 \pm 3.2$ \\
\hline F8 & $3.1 \pm 0.02$ & PASS & $0.38 \pm 0.04$ & $99.89 \pm 4.2$ \\
\hline F10 & $3.2 \pm 0.01$ & PASS & $0.12 \pm 0.04$ & $99.97 \pm 3.2$ \\
\hline F11 & $3.2 \pm 0.03$ & PASS & $0.24 \pm 0.02$ & $99.24 \pm 2.1$ \\
\hline F12 & $3.1 \pm 0.04$ & PASS & $0.16 \pm 0.03$ & $99.62 \pm 1.2$ \\
\hline
\end{tabular}

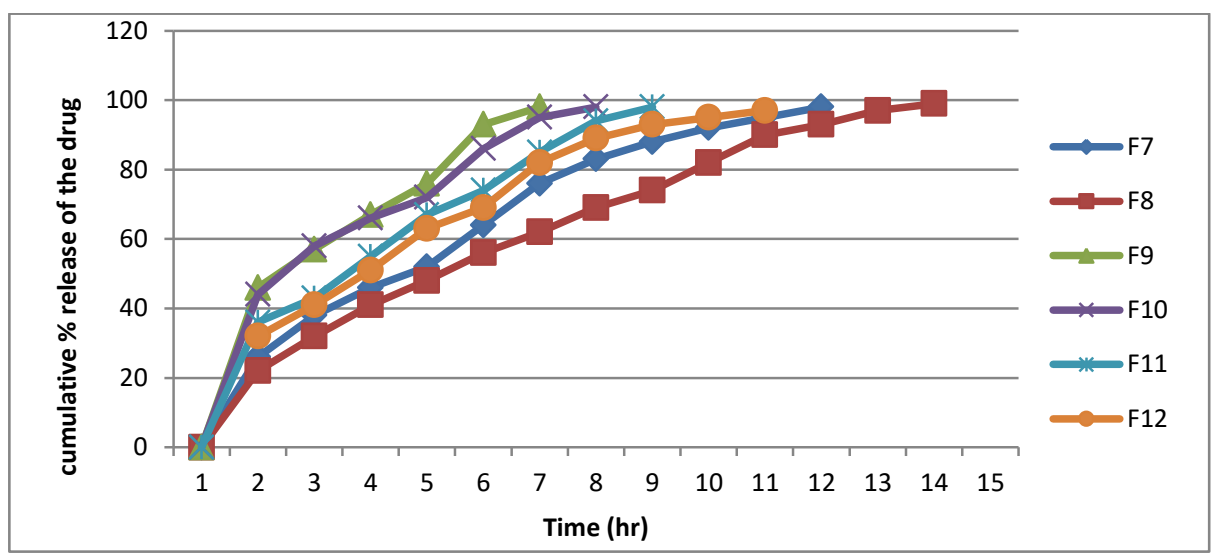

Figure 6: In vitro cumulative percentage of drug release 


\section{DISCUSSION}

The description of the drug was observed visually. The solubility data revealed that the drug is freely soluble and is a member of class III drugs according to the BCS classification. The LOD data was observed indicating that the API is non-hygroscopic. The melting point of the Metformin was performed using melting point apparatus. The particle size analysis was performed by microscopic method. The Flow indices Hausners ratio and Compressibility index shows that API has good flow.

Consequently, direct compression was followed for the manufacture of sustained release tablets. FTIR spectra of the pure drug have been shown by the graph. The broad peak at $3897.44 \mathrm{~cm}$ in the spectra of the pure drug corresponds to $\mathrm{N}-\mathrm{H}$ (stretching). The peak at $1002.05 \mathrm{~cm}$ corresponds to $\mathrm{S}=0$ (stretching), the peak at $1155.47 \mathrm{~cm}-1$ for $\mathrm{C}-\mathrm{O}-\mathrm{C}$ (stretching). The drug and polymers employed were found to be compatible as similar peaks were observed with minor differences. The $\lambda$ max of Metformin in $6.8 \mathrm{pH}$ phosphate buffer was scanned and found to have the maximum absorbance at $300 \mathrm{~nm}$.

Standard graph of Metformin in 6.8pH phosphate buffer was plotted and regression was 0.997 . The formulations were prepared with natural polymers like manila copal, guar gum and pectin and then evaluated. The angle of repose values obtained for the formulations ranged from 20.48 to 27.40 . This indicates good flow property of the powder blends. The compressibility index values for the formulations ranged from 11.36 to 21.8 . This also indicates the powder blend have good flow property. The total weight of each formulation was not maintained uniformly however the weight variation of the tablets within the limits of $5 \%$. The measured hardness of tablets in all batches was ranged from $3.0-3.2 \mathrm{~kg} / \mathrm{cm}^{2}$.

Friability values were found to be less than $1 \%$ in all prepared formulations and considered to be satisfactory. In vitro drug release profiles for all formulations were carried out by using $6.8 \mathrm{pH}$ phosphate buffers as dissolution medium for about 24 hrs. From the above results it was found that the release of drug from formulation F8 which was composed of Guar gum at $60 \mathrm{mg}$ gave the better release, drug content, friability, hardness than other formulations. The drug release from all the formulations were followed Higuchi mode l.

\section{CONCLUSION}

The findings of the present study demonstrate that the hydrophilic matrix of HPMC alone could not control the Metformin $\mathrm{HCl}$ release effectively for $12 \mathrm{~h}$, whereas, when combined with Guar gum, it could slow down the release of the drug from their matrices and can therefore be successfully employed for formulating SR matrix tablets. Diffusion coupled with erosion might be the mechanism for the drug release, which can be expected to reduce the frequency of administration and decrease the dosedependent side-effects associated with repeated administration of conventional Metformin $\mathrm{HCl}$ tablets.

\section{ACKNOWLEDGMENTS}

We are thankful to Dr. Mohd. Azaz Khan, Director and Dr. Megha Jha, Manager (Research and Development), Pinnacle Biomedical Research Institute (PBRI) Bhopal, India to provide us all lab facilities.

\section{REFERENCES}

1. Andhale VA, Patil PR, Dhas AU, Chauhan PD, Desai S V. Liposome: An emerging tool in drug carrier system. Int J Pharm Technol, 2016; 8:10982-11011.

2. Aulton ME. Pharmaceutics.The Science of Dosage Form Design.2nd edn. Churchill Livingstone, London: Harcourt Publ Limited; 2005. pp. 296-8.

3. Rathore AS, Jat RC, Sharma N, Tiwari R. An Overview : Matrix tablet as controlled drug delivery system. Int J Res Dev Pharm Life Sci, 2013; 2:482-492.

4. Remington R. The Science and Practice of Pharmacy.21st ed. Wolter Kluwer Health; 2011.pp. 939 -964.

5. Songire PR, Aher SS, Saudagar RB. Recent research on matrix tablets for controlled release-a review. Asian J Pharm Technol, 2015; 5:214-221.

6. Chugh I, Seth N, Rana AC, Gupta S. Oral sustain release drug delivery system: An overview. International Research Journal of Pharmacy, 2012; 3: 57-62.

7. Pundir S, Badola A, Sharma D. Sustained release matrix technology and recent advance in matrix drug delivery system: A review. Int J Drug Res Tech Int J Drug Res Technol, 2016

8. Brahmankar DM, JaiswalSB. Biopharmaceutics and Pharmacokinetics: Pharmacokinetics. 2nd ed. Delhi: VallabhPrakashan; 2009. pp. 399-401.

9. Patel H, Panchal DR, Patel U, Tushar, Brahmbhatt MS. Matrix type drug delivery system: A review. Journal of Pharmaceutical Science and Bioscientific Research, 2011; 1:143- 151.

10. Kumar S, Kumar H, Kumar R, Kumar A, Malodia K. Design, development and characterization of salbutamol sulphate extended release matrix tablets. Research Journal of Pharmaceutical, Biological and Chemical Science, 2013; 4:270277.

11. Manish J, Abhay K. Sustained release matrix type drug delivery system: A review. Journal of Drug Delivery and Therapeutics, 2012; 2:142-148.

12. Ghori MU, Conway B. Hydrophilic matrices for oral control drug delivery. Am J PharmacolSci, 2015; 3:103-109.

13. Basak SC, Jayakumar RB, Lucas Mani K. Formulation and release behaviour of sustained release Ambroxol hydrochloride HPMC matrix tablet. Indian J Pharm Sci, 2006; 68:594- 8. 